\title{
Üretme-Satın Alma Karar Problemi için Otomotiv Yedek Parça Sektöründe Bütünleşik Bulanık DEMATEL ve Bulanık TOPSIS Uygulaması
}

\author{
Alper KİRAZ ${ }^{*}$, Necdet GÜRSOY ${ }^{2}$ \\ Geliş / Received: 18/04/2019 \\ Revize / Revised: 10/11/2019 \\ Kabul / Accepted: 12/11/2019 \\ ÖZ \\ Üretme-satın alma kararlarının verilmesinde karar vericilerin kolay karar verememesinin nedeni karar vericilerin \\ değerlendirmesi gereken çok sayıda ana ve alt kriterin olmasıdır. Aynı zamanda bu kriterler farklı departmanların \\ yorumlarının alınmasını gerektiren çok disiplinli bir sistematiğe ihtiyaç duymaktadır. Bu sebeple bu çalışma \\ günümüzde işletmelerin en kritik karar verme konularından biri olan "Üretme-Satın Alma Kararları"nın \\ verilmesinde karar vericilere bir rehber olması amacıyla hazırlanmıştır. Bu çalışmada üretme-satın alma \\ kararlarının verilmesindeki sebepler ve üretme-satın alma kararlarının verilmesindeki teknikler üzerinden bir \\ literatür araştırması yapılmıştır. Bu araştırmalar sonrasında da otomotiv yedek parça sektöründe örnek bir üretme- \\ satın alma karar problemi çok kriterli karar verme yöntemlerinden Bulanık DEMATEL ve Bulanık TOPSIS \\ yöntemleri ile bütünleşik bir çözüm önerisi sunulmuştur.
}

Anahtar Kelimeler- Üretme-Satın Alma Kararları, Çok Kriterli Karar Verme, Bulanık DEMATEL, Bulanık TOPSIS, Otomotiv Yedek Parça Sektörü

*Sorumlu yazar iletişim: kiraz@sakarya.edu.tr_(https://orcid.org/0000-0001-7067-1473)

${ }^{1}$ Endüstri Mühendisliği, Sakarya Üniversitesi, Sakarya.

2İletişim: necdet.gursoy@ogr.sakarya.edu.tr (https://orcid.org/0000-0002-4119-4695)

Endüstri Mühendisliği, Sakarya Üniversitesi, Sakarya. 


\title{
Integrated Fuzzy DEMATEL and Fuzzy TOPSIS Application in Automotive Spare Parts Industry for Make-or-Buy Decision Problem
}

\begin{abstract}
The reason why decision makers can not make easy decisions in make-or-buy decisions is that there are lots of main and sub-criteria that decision makers need to evaluate. At the same time these criteria require a multidisciplinary systematic that requires the interpretation of different departments. For that reason, this study has been prepared as a guide for decision makers in the "Make-or-Buy Decisions" of companies which is one of the most critical decision making issues. In this study, a literature research has been made for finding the reasons and for the techniques behind make-or-buy decisions. After these investigations, a solution proposal integrated with Fuzzy DEMATEL and Fuzzy TOPSIS methods has been presented for an exemplary make-or-buy decision problem in automotive spare parts industry.
\end{abstract}

Keywords- Make-or-Buy Decisions, Multi-Criteria Decision Making, Fuzzy DEMATEL, Fuzzy TOPSIS, Automotive Spare Parts Industry 


\section{I.GIRIŞ}

Günümüz dünyasında artan rekabet koşulları altında işletmelerin hayatlarını idame ettirmeleri çok kritik bir durum haline gelmiştir. Bu durumda olan işletmeler bir yandan pazar paylarını arttırmaya çalışıp bir yandan da maliyetlerini düşürerek karlılıklarını ve şirketin genel amaçlarından biri olan literatürde FAVÖK (Faiz, Amortisman ve Vergi Öncesi Kar) olarak geçen değerinin yükselmesini sağlamaya çalışmaktadırlar. Bu görev işletmelerin Genel Müdürlerinin temel görevidir. Bu görevin başarıyla yerine getirilmesinden sorumlu kişiler ise işletmenin içindeki birçok departmanın yöneticileridir diyebiliriz. Kısacası bu temel görev işletme içinde dağılmış olan bazı performans değerlendirme kriterlerinden beslenir. Bu performans değerlendirme kriterlerinden en önemlilerini barındıran departman ise Satın Alma Departmanıdır. Satın Alma Departmanları son yıllarda artan global fiyat hareketlilikleri nedeniyle dikkat çeken bir departman halini almıştır.

Son yıllarda rekabetin küresel ortama iyice yayılmasıyla birlikte Türkiye'de ve Dünyada işletmelerin maliyetlerinin yarısından fazlasını satın alma maliyetleri oluşturmaktadır. $\mathrm{Bu}$ da işletmelerde Satınalma Departmanları'nın ya da Satınalma Departmanları'nı da kapsayan Tedarik Zinciri Departmanları'nın çok daha kritik bir duruma gelmesine sebep olmuştur. Tedarik maliyetlerinin genel ürün maliyetleri içerisindeki payının artışıla birlikte işletmeler müşteriye sevk edecekleri ürünlerin tüm alt komponentleri ile ilgili üretme-satın alma kararlarını çok daha sıkı kontrolden geçirmeye başlamışlardır. Bu kontrollerin artışıyla birlikte işletmelerde Maliyet Kontrol adı altında yeni departmanların oluşumu da son yıllarda oldukça fazla oranlarda artış göstermektedir.

Üretme-satın alma kararları noktasında karar vericiler birbirleriyle çelişen birden fazla kriter içerisinde karar verme durumunda kalmaktadırlar. Aynı zamanda karar verilirken değerlendirilen kriterler ölçülebilen ve ölçülemeyen kriterlerden oluştuğu için böyle bir ortamda geleneksel matematiksel yaklaşımlar bu problemlerin çözümlerinde yetersiz duruma gelmeye başlamışlardır. Bu sebeple son yıllarda üretme-satın alma kararlarının verilmesinde literatürdeki ÇKKV (Çok Kriterli Karar Verme) yöntemleri üretme-satın alma kararlarının çözümlerinde çözümü kolaylaştırmakta ve karar vericilerin de doğru kararlar vermelerini sağlamaktadır.

\section{A. Literatür Araştırması - Üretme-Satın Alma Kararları}

Üretme-satın alma kararları ilk kez 1915'te Ford ve Porter tarafından literatüre girmiştir. Ford ve Porter değişen durumlarda üreticilerin üretme-satın alma kararlarını sürekli olarak vermeleri gerektiğini dile getirmişlerdir [10]. Sonrasında 1937 yılında Coase Economica dergisinde yayınlanan "The Nature of the Firm" yani "Firmaların Doğası" adlı makalesinde "Firmalar neden vardır?" sorusunu dile getirerek özünde bir örgüt teorisi yaklaşımı olan fakat üretme-satın alma kararlarının da temellerinden olan İşlem Maliyetleri Yaklaşımı'nın temellerini atmış oldu [6]. Williamson ise 1975 yılında yine örgütsel bir yaklaşım kitabı olan "Markets and Hierarchies" yani "Pazarlar ve Hiyerarşiler" adlı kitabında bu yaklaşımı şekillendirmiş ve daha fazla uygulanabilir bir hale getirmiştir [29].

Hayır amacıyla kurulmamış tüm organizasyonların en büyük ortak amacı karlılıktır. Karlılık, organizasyonların tüm süreçlerinde sürekli olarak gözden geçirilmesi gereken ve şirketlerin hayatlarını devam ettirebilmeleri için gereken en temel faktördür. Satın alma faaliyetlerinde ise karlılık satın alma faaliyetlerinin en başında gerçekleştirilmelidir. Satın almaya başlanılan bir ürün eğer ederinden pahalı alınmaya başlandıysa sonraki yıllarda sağlanan tasarrufun herhangi bir etkisi olmaz çünkü sürecin başında eder derecesinde satın alma yapmayı sağlayan firmalar her zaman pazarın kaymağını alır ve rekabette de sürekli olarak ön sıralarda yer alır. Bununla birlikte işletmeler üretim için kullandıkları girdileri kendi içlerinde üretme yeteneğine de sahip olabilirler ya da bir kısmını üretme bir kısmını satın alma şeklinde de yapılar kurabilirler. Bu seçeneklerin hepsi işletmelerin karlılıklarını doğrudan etkileyen faktörlerdir.

Üretme-satın alma kararları karlılık yönüyle işletmeler için çok büyük önem arz etmekteyken; aynı zamanda çok büyük bir karar verme sürecini içine almaktadır. Üretme-satın alma kararları genel olarak karlılığın en büyük belirleyicisidir ve şirketlerin mali yapılarında kritik bir öneme sahiptirler [27].

Üretme-satın alma karar verme sürecini genel olarak şirketlerde belirli birimler yönetiyor olsa da bu sürece şirketler içindeki farklı disiplinler/departmanlar da katkıda bulunmaktadır. Üretme-satın alma kararları, farklı birimlerden gelen birçok girdiyi kullanır ve yapılandırılmış stratejik bir yaklaşım getirir [11]. Çoğu zaman 
tek amaç kısa vadeli maliyet avantajları elde etmektir [25]. Bununla birlikte Probert tarafından yapılan araştırma, üretici firma yöneticilerinin üretme-satın alma kararının şirket stratejisinin bir parçası olması gerektiğine inandığını göstermektedir [23].

Üretme-satın alma problemi ile ilgili geniş bir araştırma alanı bulunmasına rağmen önerilen birçok model ve metodolojiler dar bir şekilde finansal düşüncelere dayanmaktadır. Başka türlü ifade etmek gerekirse üretmesatın alma analizi genellikle maliyet muhasebesi ve/veya nakit akışı modellerinin kullanımıyla sınırlı kalmaktadır. Finansal performans üretme-satın alma kararlarının verilmesinde önemli bir rol oynamasına rağmen genel olarak tek önemli faktör değildir. Karar sürecine maliyetin yanı sıra diğer kriterlerin dahil edilmesi firma tarafından alınacak olan karar türünü büyük ölçüde etkileyecek potansiyele sahip olacaktır [21].

Kısacası literatürde yer alan tanımlardan da anlaşılacağı üzere üretme-satın alma kararları sadece maliyet unsurlarını içeren bir karar problemi değil bunun yanında çok farklı departmanları ve bilim alanlarını ilgilendiren stratejik bir karar sürecidir. Bunun yanında her bilim dalı bu karar verme sürecini farklı bakış açılarıyla yorumlamıştır.

Çalışmanın ikinci bölümünde üretme-satın alma kararlarının verilmesindeki sebepler, üçüncü bölümünde üretme-satın alma kararlarının verilmesinde kullanılan ÇKKV teknikleri kısaca bir tablo üzerinden aktarılmıştır. Makalenin dördüncü bölümünde örnek uygulamada kullanılan ÇKKV tekniklerinden Bulanık DEMATEL ve Bulanık TOPSIS yöntemlerinin nasıl uygulandığı aktarılmış ve beşinci bölümde de otomotiv yedek parça sektöründeki bir üretme-karar verme problemi için kurulan karar modelinin uygulama adımları açıklanmıştır.

\section{I ÜRETME-SATIN ALMA KARARLARININ VERILMESINNDEKİ SEBEPLER}

Firmalar kendi üretimlerinde kullanmaları gereken malzemelerin tamamını üretip bitmiş ürün ortaya çıkartabileceği gibi tamamını satın alıp son operasyonları yaparak da bitmiş ürün elde edebilirler fakat üretmesatın alma kararlarının verilmesindeki etkenler yani üretme-satın alma kararlarının verilmesine firmaları zorlayan sebepler vardır. $\mathrm{Bu}$ sebepler firmaların maliyet yapısı, kapasite durumu vb. kendi iç özelliklerine göre değişebileceği gibi herhangi bir t anındaki firmaların üretme-satın alma kararlarına firmaları yönlendiren sebeplerle başka bir zamandaki sebepler de birbirinden farklı olabilir. Örneğin sadece kapasite yetersizliğinden dolayı üretme-satın alma kararı yapmak zorunda kalan bir firma sonraki dönemlerde yapacağı yatırımlarla kapasitesini arttırabilir dolayısıyla da artık kapasite firmayı üretme-satın alma kararına yönlendiren sebep olmaktan çıkmıştır fakat yeni durumda da maliyet baskısı firmayı bu kararı verdirmeye yönlendiren bir etken olabilir. Örneğin; Moschuris 2007 yılında hazırladığı makalede üretme-satın alma kararlarının verilmesindeki sebeplerin öneminin organizasyon karakteristiklerine ve ürün/hizmet karakteristiklerine göre değişebileceğini belirtmiştir [18].

\section{A. Üretme-Satın Alma Kararlarının Verilmesindeki Sebepler}

Literatürde bu konuda çok sayıda değerlendirme yapılmıştır fakat bu değerlendirmelerden birçoğu birbirlerini tekrar eden yaklaşımlar olduğu için örnek olması açısından üç farklı yazarın değerlendirmesi aşağıda açıklanmaya çalışılmıştır;

Bergen 1977 yılında yayınladığı makalesinde üretme-satın alma kararının üretim şirketlerinin ekonomisi için kritik öneme sahip olduğunu belirtmiş ve aynı zamanda üretme-satın alma kararının genel olarak kabul edilenden daha sıklıkla ve daha çok sayıda şirket işlevi tarafından alındığını belirtmiştir. Bu kararlardan etkilenen şirket faaliyetlerinin geniş yelpazesi ve bunlara dahil olan çok sayıda departman nedeniyle, genel değerlendirmenin bir parçasını oluşturmaktan ziyade, departman değerlendirmelerine ilişkin karar kriterleri ile, anlık bazda ele alınmaları tehlikesi vardır [2].

Bergen satın almanın ve üretmenin uygun olduğu durumları aşağıdaki gibi aktarmıştır [2]. Satın almanın uygun olduğu durumlar;

- Fabrikanın kapasitesini arttırma ihtiyacı olduğunda

- Açık ve rekabetçi pazarda özel bir teknolojiyi elde etme ihtiyacı olduğunda

- Daha iyi fiyatlar elde etmek istendiğinde 
- Ticari pozisyonu geliştirmek istediğinde

- Sermaye yatırımlarını önlemek istediğinde

Üretmenin uygun olduğu durumlar;

- Açık ve rekabetçi bir pazar yoksa

- Üretim kapasitesi ve yeterliliği uygunsa

- Dışarıda yaptırılacak olan iş fabrikadaki iş yükü azaldığında şirket içine alınamazsa

- Katma değeri yüksek bir iş ise

- Tek bir kaynak oluşacak ve tedarikçilerin güvenilirliği şüpheli aynı zamanda normal teknolojilerini geliştirme olanağı bulacaklarsa

- Şirket tarafindan üst düzey bir denetime ihtiyaç varsa

- Özel ve tedarikçi için düşük hacimli bir iş ise

- Derinlemesine teknolojinin bilgisi şirket için önemliyse

Platts ve arkadaşları 2002 yılında yayınladığı makalede üretme-satın alma kararları sürecini bir şemada göstermiş ve bu şemanın ilk aşamasında üretme-satın alma kararlarının tetikleyicilerini açıklamıştır [22]. Platts 2000 yılında Canez ve Probert ile birlikte yayınladıkları makaledeki üretme-satın alma kararları için oluşturdukları çerçeve içindeki tetikleyicileri 2002 yılında hazırladığı makalede de kullanmıştır. Kısacası üretme-satın alma kararlarını tetikleyen sebepler aşağıdakilerdir [5];

- Maliyet düşürme

- Kapasite yetersizliği

- Pazara çıkma süresini kısaltmak

- Kaliteyi arttırmak

- Yeni ürün tanıtımı

- Odak yatırım

- Yetenekleri dengelemek

- Beceri eksikliği

- Cevap verebilirliği arttırmak

$\mathrm{Bu}$ konuda yapılan en güzel araştırmalardan birisi Hwang ve arkadaşlarının 2007 yılında hazırladıkları makalede sunulmuştur. Hwang ve arkadaşları 2007 yılında yayınlanan makalelerinde üretme-satın alma kararlarının verilmesindeki faktörleri 19 ana faktör ve onların ana başlıkları şeklinde değerlendirmişlerdir [12]. Aşağıda Tablo 1'de bu faktörler belirtilmiştir.

Tablo 1. Üretme-satın alma kararlarının verilmesindeki faktörler

\begin{tabular}{|c|c|}
\hline Başlıklar & Ana Faktörler \\
\hline \multirow{4}{*}{ Üretim Teknolojisi } & Rekabet Avantajı için Teknolojinin Önemi \\
\hline & Teknolojinin Olgunluğu \\
\hline & Teknolojinin Belirsizliği \\
\hline & Gelecekteki Gelişmelerin Olasılı̆ı̆ \\
\hline \multirow{4}{*}{ Dış Satın Alma Riski } & El Koyma Riski (Kendine ait Hissetme) \\
\hline & Teknolojinin Yayılmas1 \\
\hline & Son Ürün Bozulması \\
\hline & Karșılaștırma (Kıyaslama) \\
\hline \multirow{4}{*}{ Yönetimsel Konular } & İș Gücü İstikrarı \\
\hline & Planlama, Kontrol veya Denetimde Karmaşıklık Seviyesi \\
\hline & Tedarik Güvenilirliği ve Güvencesi \\
\hline & Karșılaștırma (Kıyaslama) \\
\hline \multirow[t]{3}{*}{ Finansal Konular } & Maliyet \\
\hline & Yatırım \\
\hline & Yatırımın geri dönüșü \\
\hline \multirow{4}{*}{ Operasyonel Konular } & Üretim yetkinliği \\
\hline & Kalite \\
\hline & Termin süresi \\
\hline & Hacim belirsizliği \\
\hline
\end{tabular}




\section{B. Otomotiv Yedek Parça Sektöründe Üretme-Satın Alma Kararlarının Verilmesindeki Sebepler}

Gerek otomotiv sektöründe gerekse farklı sektörlerde olsun genel anlamda yedek parça demek çeşitlilik demektir. Otomotiv yedek parça sektöründe de firmalar kendilerinin üstün özelliklerini anlatırken birçok özellik anlatır fakat en ön planda kaç farklı çeşit ürüne sahip olduklarını anlatırlar. Türkiye'de de otomotiv yedek parça sektöründe üretme-satın alma kararlarının verilmesindeki ana faktörler aşağıldaki gibi belirtilmiştir;

- Çin gibi bir ülkenin yedek parça sektöründe lider rekabet ortamında fiyat baskısı

- Müş̧erilerden gelen ürün çeşitliliği talebi

- Ürünün pazara sürülmesi için geçen süre

- Yatırım maliyeti

- Talep dalgalanmalarından etkilenme

- Tedariğin aksamasi/kesilmesi riski ve nakliye maliyetleri

- Değişiklik yönetimi

- Açık ve rekabetçi pazarda özel teknolojiyi elde etme ihtiyacı

\section{III.ÜRETME-SATIN ALMA KARARLARININ VERILMESINNDE KULLANILAN ÇKKV TEKNIKLERİ}

Literatür araştırmasında kavramsal ve sayısal metotlar kullanarak üretme-satın alma problemlerini çözen yazarların yöntemlerini incelediğimizde genel olarak yazarların bir model oluşturup bu model üzerinden aşama aşama ilerleyip üretme-satın alma kararlarının verileceği sonuçlar elde etmeye çalışmışlardır. Bunlarla birlikte İşlem Maliyetleri Yaklaşımı'nın ortaya çıkmasından sonra da özellikle bu yaklaşımı kullanarak bu karar verme probleminin çözümünü bulmaya çalışan birçok yazar olmuştur. 2000'li yılların başlarına kadar bu metodolojiler kullanmaya devam etmiş fakat bu yıllardan sonra özellikle ÇKKV yöntemlerinin hakimiyeti belirgin olmaya başlamıştır [3]. ÇKKV yöntemleri daha gerçekçi senaryolarla, kararı çok sayıda etkileyen kriterlerin birlikte ele alındığı, çok boyutlu karar verme problemlerinin çözümüne olanak sağlamaktadır [1].

Literatürde üretme-satın alma kararlarını ÇKKV yöntemleriyle ele alan çalışmalar ve çalışmaların kısa özetleri Tablo 2'de verilmiştir.

Tablo 2. Literatürde üretme-satın alma kararlarının ÇKKV yöntemleriyle ele alındığı çalışmalar

\begin{tabular}{|c|c|c|c|}
\hline Sira & Yazar(lar) & Yil & Kapsam ve Kullanılan Yöntem \\
\hline 1 & $\begin{array}{l}\text { Padillo ve } \\
\text { Diaby }\end{array}$ & 1999 & $\begin{array}{l}\text { AHP } \\
\text { Üretme-satın alma kararları için AHP ile dört seviyeli bir model önermiştir [21]. } \\
\text { AHP }\end{array}$ \\
\hline 2 & Öncü ve ark. & 2006 & $\begin{array}{l}\text { Firmaların üretme-satın alma kararlarını ülkelere yaymış ve ülkeler için ithalat veya milli üretim olarak } \\
\text { değerlendirip bu kararlar için AHP kullanmışlardır [19]. } \\
\text { AHP }\end{array}$ \\
\hline 3 & Water ve Peet & 2006 & $\begin{array}{l}\text { Literatürde yer alan üretme-satın alma mevcut modellerinin temel elemanlarıyla bir AHP uygulaması } \\
\text { yapmıştır [25]. } \\
\text { Bulanı AHP }\end{array}$ \\
\hline 4 & Hwang ve ark. & 2007 & $\begin{array}{l}\text { Web tabanlı ve iki aşamalı bir model geliştirdiler. 1.aşama beyin fırtınası, 2.aşama AHP ile model } \\
\text { geliştirme [12]. }\end{array}$ \\
\hline 5 & Wang ve Yang & 2007 & $\begin{array}{l}\text { Dış kaynak kullanımı için } 6 \text { kriterli bir model geliştirdiler. AHP ile kriter ağırlıkları bulunup, } \\
\text { PROMETHEE ile alternatif sıralaması yapılmıștır [26]. }\end{array}$ \\
\hline 6 & $\begin{array}{l}\text { Kahraman ve } \\
\text { ark. }\end{array}$ & 2008 & $\begin{array}{l}\text { Bulanık TOPSIS } \\
\text { Dış kaynak kullanımını bulanık TOPSIS ile modellemişlerdir [13]. } \\
\text { AHP. Bulanık AHP. ANP. PROMETHEE }\end{array}$ \\
\hline 8 & Cheshmberah & 2010 & $\begin{array}{l}2 \text { aşamalı bir model geliştirdiler. 1.aşama faaliyetin ana yetkinlik olup olmadığı değerlendirilir, } \\
\text { 2. aşamada Bulanı TOPSIS uygulaması [8]. } \\
\text { AHP }\end{array}$ \\
\hline 9 & Minh & 2011 & $\begin{array}{l}\text { Japonyada otomotivde kullanılan parçaların üretme-satın alma kararları ile ilgili değerlendirmeyi AHP } \\
\text { ile yapmıştır [17]. }\end{array}$ \\
\hline 10 & Şentan & 2013 & $\begin{array}{l}\text { DEMATEL, ANP, TOPSIS } \\
\text { Savunma Sanayi helikopter projesi için } 3 \text { yöntemli bir metod geliștirerek alternatifleri sıralamıștır [24]. }\end{array}$ \\
\hline
\end{tabular}




\section{METODOLOJI}

$\mathrm{Bu}$ çalışmada kriterler arasındaki etkileşimin tümünün nicel olarak ifade edilmesinin mümkün olmamasından dolayı kriterlerin ağırlıklarının belirlenmesinde DEMATEL yöntemi bulanık küme teorisi ile genişletilerek Bulanık DEMATEL yöntemi kullanılmıştır. Üretme-satın alma kararının alternatifleri arasında en iyi çözümü bulmak amacıyla da karar verme sürecinde insan yargılarının sebep olduğu belirsiz durumları ortadan kaldırmak için TOPSIS yöntemi bulanık küme teorisi ile genişletilerek Bulanık TOPSIS yöntemi kullanılmıştır.

\section{A. Bulanık Mantık}

Bulanık mantık Lotfi A. Zadeh'in 1965 yılında yayınlanan Bulanık Kümeler isimli makalesinin "Information and Control" dergisinde çıkmasıyla ortaya atılmış oldu [28]. Bulanık mantık, insanın düşünme biçiminden esinlenilerek geliştirilmiş, bulanık küme teorisine dayanan genel bir hesaplama sistemidir ve bu sistemde kullanılan dilsel değişkenler ile mantıksal ifadeler arasında bağıntılar bulunmaktadır [14]. Gerçek hayatta üretme-satın alma kararlarında olduğu gibi birçok karar verme probleminde kararlar, karar kriterleri ve alternatifler kesin olarak bilinmez. Belirsizlik ortamında insanlar karar vermek için genel olarak olasılık teorisi, karar teorisi gibi teorileri kullanmışlardır. Bu durumda ise belirsizlik ile rassallık kavramları birbirlerini dengelerler. Rassallık bir kümeye üye olmak ya da olmamak arasındaki belirsizlik iken bulanıklıkta üye olmak ya da olmamanın dışında derecelendirilmiş üyelikler de mevcuttur. Kısaca değerlendirmek gerekirse bulanık mantık "evet-hayır", "doğruyanlış" gibi kavramlar yerine "çok az, az, orta, yüksek, çok yüksek" gibi ortalama değerleri kullanarak dereceli veri modellemesi yapmaktadır. Güncel hayatta da örnek vermek gerekirse havanın sıcak ya da soğuk olmasını "bugün biraz soğuk, bugün hava çok soğuk, havalar biraz ısındı" gibi kelimelerle anlatırız. Bulanık mantığın amacı da günlük hayatta kullanılan bu kelimeleri matematiksel ifadelere dökmektir. Bulanık küme üyeler arasındaki kesin geçişlerin elenerek belirsizlik kavramını ortaya çıkartarak kümedeki tüm üyelere üyelik derecesi verir ve matematiksel olarak tanımlar. Klasik küme yaklaşımında iki seviyeli sistem [0,1] varken bulanık küme, bulanık mantık yaklaşımında $[0,1]$ arasında çok seviyeli bir sistem kullanır.

Bulanık sayılar çok çeşitli olsa da teoride de uygulamalarda da en fazla kullanılan bulanık sayılar üçgen bulanık sayılardır. Üçgen bulanık bir sayı (1, m, u) şeklinde gösterilir. "l” değeri mümkün olan en küçük değeri, "m" değeri en çok beklenen değeri ve "u" değeri de mümkün olan en büyük değeri ifade eder. Şekil 1 'de üçgen bulanık sayının gösterimi yer almaktadır.

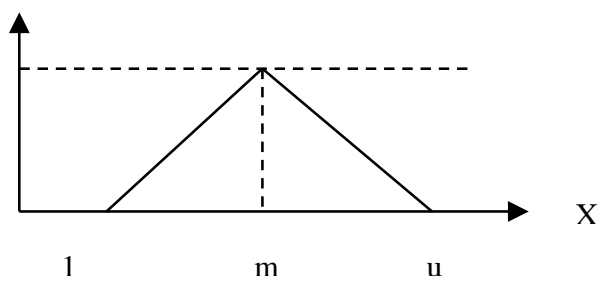

Şekil 1. Üçgen bulanık sayı

\section{B. Bulanık DEMATEL}

DEMATEL yöntemi 1973 yılında Fontela ve Gabus tarafından ortaya atılmış olan bir ÇKKV yöntemidir. $\mathrm{Bu}$ yöntem de diğer ÇKKV yöntemleri gibi uzmanların deneyim ve görüşlerini karar verme problemlerinin analizlerinde kullanmaktadır. Bu yöntem karmaşık kriterler arasındaki ilişkileri sebep sonuç ilişkisi açısından dikkate alarak kriterler arasındaki ilişkilerin ağırlıklarının değerlendirilmesini sağlar.

DEMATEL yöntemi karar verme sürecini etkileyen çok sayıda faktör arasındaki sebep sonuç ilişkisini görselleştirerek anlamlı sonuçlar çıkartmaya çalışır fakat tüm kriterler nicel yani sayısal olarak ifade edilemediğinden dolayı bu kriterleri ifade etmek zordur. Bu zorluğu ortadan kaldırmak için bulanık küme teorisi 
kapsamında kriterler alınan uzman görüşleri sonrasında bulanık sayılara dönüştürülür. Kısacası DEMATEL yöntemi bulanık ortama taşınır [16]. Literatürde Bulanık DEMATEL özellikle 2000'li yıllar ile birlikte çok daha sıklıkla yerini bulmaya başlamıştır fakat genel olarak makine seçimi, tedarikçi seçimi, üçüncü parti lojistik firma seçimi gibi seçim süreçlerinde kriterler arasındaki önem derecelerini bulmak için uygulanmış. Üretme-satın alma karar verme süreci için kullanılmamıştır.

Bulanık DEMATEL yönteminin uygulanması için sırasıyla aşağıdaki adımlar izlenir [16, 9, 4];

1.Adım: Kriterlerin belirlenmesi ve bulanık değerlendirme skalasının oluşturulması

$\mathrm{Bu}$ adımda uzman görüşleri tarafından ortaya çıkartılan karar verme probleminde etkisi bulunması gerektiği düşünülen tüm kriterler belirlenir. Sonrasında belirlenen bu kriterler arasında ikili karşılaştırmalar yapılır fakat bu karşılaştırmaları yaparken bir kriterin diğer bir kriteri ne derece etkilediği dilsel değişken olarak düşünülmüş, bunların karşısında bir sayısal skala ve onun da karşısında bir bulanık skala ortaya koyulmuştur [15]. Bu bulanık skala Tablo 3'te gösterilmiştir.

Tablo 3. Dilsel değişkenler, sayısal ve bulanık karşıllıkları

\begin{tabular}{ccc}
\hline Dilsel Değişkenler & Sayısal Karşılıklar & Bulanık Karşılıklar \\
\hline Çok az etkili & 0 & $(0,00 ; 0,00 ; 0,25)$ \\
\hline Az etkili & 1 & $(0,00 ; 0,25 ; 0,50)$ \\
\hline Normal etkili & 2 & $(0,25 ; 0,50 ; 0,75)$ \\
\hline Çok etkili & 3 & $(0,50 ; 0,75 ; 1,00)$ \\
\hline Çok fazla etkili & 4 & $(0,75 ; 1,00 ; 1,00)$ \\
\hline
\end{tabular}

2.Adım: Bulanık direkt ilişki matrisinin oluşturulması

$\mathrm{C}=\left\{\mathrm{C}_{\mathrm{i}} \mid \mathrm{i}=1,2, . ., \mathrm{n}\right\}$ kriterleri arasındaki ilişkilerin belirlenmesi için $\mathrm{p}$ tane uzman kişiden oluşan bir karar verici grup yukarıda verilen dilsel değişkenlerin karşılığı olan sayısal karşılıklarla kriterler arasındaki etkileşimi çıkarmak için ikili karşılaştırmalar yaparlar. Bu şekilde p tane $\tilde{z}^{1}, \tilde{z}^{2}, \ldots ., \tilde{z}^{\mathrm{p}}$ bulanık matris oluşturulur.

Buna göre elemanları $i$. kriterin $j$. kriteri etkileme derecesini gösteren $k$ uzmanına ait $\tilde{z}_{\mathrm{ij}}=\left(\mathrm{l}_{\mathrm{ij}} \mathrm{m}_{\mathrm{ij}}, \mathrm{u}_{\mathrm{ij}} \mathrm{k}\right)$ üçgensel bulanık sayılarından oluşan direkt ilişki matrisi 1 numaralı formülde gösterildiği gibi olacaktır.

$$
\tilde{Z}_{k}=\left[\begin{array}{ccc}
0 & \ldots & \tilde{z}^{k}{ }_{1 n} \\
\cdot & \cdot & \cdot \\
\cdot & \cdot & \cdot \\
\tilde{z}_{n 1}^{k} & \cdot & \cdot \\
\tilde{n}_{n} & \cdot . & 0
\end{array}\right],, \mathrm{k}=1,2, \ldots, \mathrm{p} ; \quad \mathrm{i}=1,2, \ldots, \mathrm{n}
$$

3.Adım: Normalize bulanık direkt ilişki matrisinin oluşturulması

Normalize bulanık direkt ilişki matrisi 2 ve 3 numaralı formüllerle oluşturulur.

$$
\begin{aligned}
& \tilde{x}_{i j}{ }^{k}=\frac{\tilde{z}_{i j}{ }^{k}}{r^{k}}=\left(\frac{l_{i j}{ }^{k}}{r^{k}}, \frac{m_{i j}{ }^{k}}{r^{k}}, \frac{u_{i j}{ }^{k}}{r^{k}}\right) \\
& r^{k}=\max _{1<i<n}\left(\sum_{j=1}^{n} u_{i j}{ }^{k}\right)
\end{aligned}
$$

Burada direkt ilişki matrisindeki u sütunları toplanır ve onların maksimum değeri bulanık direkt ilişki matrisindeki tüm sayılar bu değere bölünür ve bu sayede normalleştirme işlemi yapıllmış olur ve aşağıdaki gibi 4 numaralı normalize bulanık direkt ilişki matrisi aşağıdaki gibi oluşur. 


$$
\tilde{X}=\left[\begin{array}{cccc}
\tilde{X}_{11} & \tilde{X}_{12} & \cdots & \tilde{X}_{1 n} \\
\tilde{X}_{21} & \tilde{X}_{22} & \cdots & \tilde{X}_{2 n} \\
\vdots & \vdots & \ddots & \cdots \\
\tilde{X}_{n 1} & \tilde{X}_{n 2} & \cdots & \tilde{X}_{n n}
\end{array}\right]
$$

4.Adım: Toplam bulanık direkt ilişki matrisinin oluşturulması oluşturulur.

Normalize bulanık direkt ilişki matrisinin üzerine formül 5 uygulanarak Toplam direkt ilişki matrisi

$$
\tilde{T}=\tilde{X}+\tilde{X}^{2}+\tilde{X}^{3}+\cdots=\sum_{i=1}^{\infty} \tilde{X}^{i}=\tilde{X}(I-\tilde{X})^{-1}
$$

Üçgensel sayılardan oluşmuş olan normalize bulanık direkt ilişki matrisine bunu uygulamak zor olduğu için 1, m, u sayılarının her birinden ayrı birer matris oluşturulup öyle uygulanır. Üç matris için de aynı işlem uygulanır yani önce birim matristen çıkarılır, sonrasında ortaya çıkan matrisin tersi alınır, en son işlem olarak da matrisin ilk haliyle çarpılır. Bu işlem üç matris için de uygulandıktan sonra üç matris de birleştirilir ve 6 numaralı toplam ilişki matrisi oluşturulmuş olur.

$$
\widetilde{T}=\left[\begin{array}{cccc}
\tilde{T}_{11} & \tilde{T}_{12} & \cdots & \tilde{T}_{1 n} \\
\widetilde{T}_{21} & \widetilde{T}_{22} & \cdots & \widetilde{T}_{2 n} \\
\vdots & \vdots & \ddots & \cdots \\
\widetilde{T}_{n 1} & \widetilde{T}_{n 2} & \cdots & \widetilde{T}_{n n}
\end{array}\right]
$$

(6)

5.Adım: Neden sonuç ilişkilerinin (Gönderici alıcı gruplarının) belirlenmesi

Toplam ilişki matrisi oluşturulduktan sonra bu matrisin sütun elemanları toplamı $\widetilde{D}_{i}$ ve satır elemanları toplamı olan $\widetilde{R}_{i}$ değerleri bulunur. Bu değerlerin toplanmasıyla $\widetilde{D}_{i}+\widetilde{R}_{i}$ ve $\widetilde{D}_{i}-\widetilde{R}_{i}$ değerleri ortaya çıkar. Bu değerler hala üçgensel bulanık sayılardan oluşmakta olduğu için bu değerlere 7 ve 8 formülleri uygulanarak durulaştırma işlemi yapılır.

$$
\begin{aligned}
& {\widetilde{D}_{i}}^{\text {def }}+\tilde{R}_{i}{ }^{\text {def }}=\frac{1}{4}\left(x_{i j, l}+2 x_{i j, m}+x_{i j, u}\right) \\
& \widetilde{D}_{i}{ }^{d e f}-\widetilde{R}_{i}{ }^{d e f}=\frac{1}{4}\left(x_{i j, l}+2 x_{i j, m}+x_{i j, u}\right)
\end{aligned}
$$

$\widetilde{D}_{i}^{d e f}+\widetilde{R}_{i}^{\text {def }}$ değeri bir kriterin diğer kriterler içindeki önemini ve toplam etkisini gösterirken, $\widetilde{D}_{i}^{\text {def }}-$ $\tilde{R}_{i}^{\text {def }}$ değeri ise kriterlerin gönderici ya da alıcı olarak iki gruba ayrılmasını sağlar. Bu değer pozitifse kriter gönderici grubunda olup diğer kriterler üzerindeki etkisi yüksektir. Ĕ̆er bu değer negatifse kriter alıcı grupta yer almakta olup diğer kriterler üzerindeki etkisi düşüktür. Bu veriler yardımıyla neden sonuç ilişki diyagramı çizilebilir, buna etki yönlü graf diyagramı da denir.

6.Adım: Ağırlıkların hesaplanması

9 numaralı formülle göre kriter ağırlıkları hesaplanır.

$$
w_{i}=\left\{\left(\widetilde{D}_{i}^{\text {def }}+\widetilde{R}_{i}^{\text {def }}\right)^{2}+\left({\widetilde{D_{i}}}^{\text {def }}-\widetilde{R}_{i}^{\text {def }}\right)^{2}\right\}^{1 / 2}, W_{i}=\frac{w_{i}}{\sum_{i=1}^{n} w_{i}}
$$

\section{Bulanık TOPSIS}

TOPSIS yöntemi 1981 yılında Hwang ve Yoon tarafından geliştirilmiş ve yaygın olarak kullanılan bir ÇKKV yöntemidir. TOPSIS yöntemi de diğer ÇKKV yöntemlerinde olduğu gibi uzman görüşlerini, karar verme sürecindeki alternatiflerin değerlendirilmesinde kullanır. TOPSIS yönteminin temel mantığında ideal çözüm için gerekli olan yakınlıklar hesaplanır ve bu yakınlıklar pozitif ideal çözüme uzaklık ile negatif ideal çözüme uzaklık 
olarak ayrı ayrı değerlendirilir. Amaç alternatifler arasında en iyi alternatifi seçmek ve bir sıralama yapmak olduğu için en iyi alternatif çözümü pozitif ideal çözüme en yakın ve negatif ideal çözüme en uzak olan alternatif verir.

Chen 2000 yılında belirsizliğin olduğu ve çok sayıda karar vericinin bulunduğu karar verme problemlerinde ortamın daha fazla gerçeği yansıtması için karar vericilerin dilsel değişkenler kullanmalarını ve bu dilsel değişkenlerin de bulanık küme teorisi kapsamında genişletilerek çözümün bulanık ortamda yapılmasını ortaya koymuş ve bu sayede Bulanık TOPSIS yöntemini ortaya çıkarmıştır [7].

Bulanık TOPSIS yönteminin uygulanması için sırasıyla aşağıdaki adımlar izlenir.

1.Adım: Karar vericilerin ve çözüm alternatiflerinin seçimi

Kararının verilmesinde yetkisi olan uzmanlardan bir karar verici grup oluşturulur ve alternatifler belirlenir.

2.Adım: Kriter ve alternatiflerin dilsel değişkenler ile değerlendirilmesi

Kriterlere göre alternatifler dilsel değişkenler ile değerlendirilir. Dilsel değişkenlerin karşıllığı bir bulanık skala oluşturulur.

3.Adım: Değerlendirmelerin bulanık sayılara dönüştürülmesi dönüştürülür.

2.adımda yapılan değerlendirmeler Tablo 3'te belirtilen bulanık skalaya göre bulanık sayılara

4.Adım: Bulanık karar matrisinin oluşturulması

Bu aşamada karar verici grubun her birinin verdiği kararların bulanık sayılara dönüştürülmesi sonucu, bu sayıların ortalaması alınarak bulanık karar matrisi oluşturulur. Karar vericiler $(\mathrm{K}$ tane $), \mathrm{C}=\left\{\mathrm{C}_{-} \mathrm{i} i \mathrm{i}=1,2, \cdots, \mathrm{n}\right\}$ ile tanımlanmış karar kriterlerini dikkate alarak A_1,A_2, $\cdots, A \_m$ alternatif çözümleri arasından değerlendirmelerini yapar. D bulanık karar matrisi 11 numarada gösterilmiş olup 10 numaralı formülasyonda gösterildiği üzere $\tilde{x}$ _ij elemanlarından oluşur ve bu elemanlar da $C_{-} j(j=1,2, \cdots, n)$ kriterlerine göre $A_{-} i(i=1,2, \cdots, m)$ alternatiflerinin performansını gösterir. $W$ ise $C_{-} j(j=1,2, \cdots, n)$ kriterlerinin önem ağırlıklarını temsil eden $w_{-} i$ elemanlarının oluşturduğu karar kriterlerinin matrisidir ve 12 numarada gösterilmiştir.

$$
\begin{aligned}
& \tilde{x}_{i j}=\frac{1}{K}\left[\tilde{x}_{i j}{ }^{1}+\tilde{x}_{i j}{ }^{2}+\cdots+\tilde{x}_{i j}{ }^{K}\right] \\
& \widetilde{D}=\left[\begin{array}{ccc}
\tilde{x}_{11} & \cdots & \tilde{x}_{1 n} \\
\vdots & \ddots & \vdots \\
\tilde{x}_{m 1} & \cdots & \tilde{x}_{m n}
\end{array}\right] \\
& W=\left[\widetilde{w}_{1}, \widetilde{w}_{2}, \cdots, \widetilde{w}_{n}\right]
\end{aligned}
$$

5.Adım: Normalize edilmiş bulanık karar matrisinin oluşturulması

4.adımda oluşturulmuş olan bulanık karar matrisi 13 ve 14 formülleriyle normalize edilir. Burada $\tilde{\mathrm{r}} \_\mathrm{ij}$ normalize edilmiş bulanık karar matrisinin elemanlarını oluşturur.

$$
\begin{array}{lll}
\tilde{r}_{i j}=\left(\frac{a_{i j}}{c_{j}^{*}}, \frac{b_{i j}}{c_{j}^{*}}, \frac{c_{i j}}{c_{j}^{*}}\right), & j \in B, & c_{j}^{*}=\max _{i} c_{i j} \\
\tilde{r}_{i j}=\left(\frac{a_{j}^{-}}{c_{i j}}, \frac{a_{j}^{-}}{b_{i j}}, \frac{a_{j}^{-}}{a_{i j}}\right), & j \in C, & a_{j}^{-}=\min _{i} a_{i j}
\end{array}
$$

Karar kriterleri fayda ve maliyet olarak ikiye ayrılabilir. 13 numaralı formülasyonda yer alan B fayda, 14 numaralı formülasyonda yer alan $\mathrm{C}$ ise maliyeti ifade etmektedirler. Normalize edilmiş bulanık karar matrisi de $\mathrm{R}^{\sim}$ ile ifade edilir ve 15 'e göre formülleştirilir. 


$$
\tilde{R}=\left[\tilde{r}_{i j}\right], i=1,2, \cdots, m, j=1,2, \cdots, n
$$

6.Adım: Ağırlıklı normalize edilmiş bulanık karar matrisinin oluşturulması gösterilmiştir.

Ağırlıklı normalize edilmiş bulanık karar matrisi $\tilde{\mathrm{v}}$ _ij elemanlarından oluşan $\tilde{\mathrm{V}}$ matrisidir ve 16 da

$$
\tilde{V}=\left[\tilde{v}_{i j}\right]=\tilde{r}_{i j} x \widetilde{w}_{j}, \quad i=1,2, \cdots, m, j=1,2, \cdots, n
$$

7.Adım: Bulanık pozitif ve negatif ideal çözümlerin belirlenmesi

$A^{*}=$ Bulanık pozitif ideal çözümü ifade eder, formül 17’ye göre hesaplanır.

$A^{-}=$Bulanık negatif ideal çözümü ifade eder, formül 18'e göre hesaplanır.

$$
\begin{aligned}
& A^{*}=\left(\tilde{v}_{1}{ }^{*}, \tilde{v}_{2}{ }^{*}, \cdots, \tilde{v}_{n}{ }^{*}\right) \quad j=1,2, \cdots, n \\
& A^{-}=\left(\tilde{v}_{1}{ }^{-}, \tilde{v}_{2}{ }^{-}, \cdots, \tilde{v}_{n}{ }^{-}\right) j=1,2, \cdots, n
\end{aligned}
$$

\section{Adım: Yakınlık katsayılarının hesaplanması}

Her bir çözüm alternatifinin bulanık pozitif ideal çözümden ve bulanık negatif ideal çözümden uzaklıkları 19 ve 20 numaralı formülasyonlara göre hesaplanır. $d_{i}{ }^{*}$ bulanık ideal çözümden olan uzaklığı, $d_{i}{ }^{-}$ise bulanık negatif ideal çözümden olan uzaklığ

$$
\begin{aligned}
& d_{i}{ }^{*}=\sum_{j=1}^{n} d\left(\tilde{v}_{i j}, \tilde{v}_{j}{ }^{*}\right), \quad i=1,2, \cdots, m \\
& d_{i}{ }^{-}=\sum_{j=1}^{n} d\left(\tilde{v}_{i j}, \tilde{v}_{j}{ }^{-}\right), \quad i=1,2, \cdots, m
\end{aligned}
$$

$\mathrm{d}(\ldots, \ldots)$ iki bulanık sayı arasındaki uzaklığı ifade eder ve Vertex yöntemine göre hesaplanır. Bu yöntem $\tilde{m}=\left(m_{1}, m_{2}, m_{3}\right), \tilde{n}=\left(n_{1}, n_{2}, n_{3}\right)$ gibi iki üçgen bulanık sayı arasındaki uzaklık 21 numaralı formüle göre hesaplanır.

$$
d(\tilde{m}, \tilde{n})=\sqrt{\frac{1}{3}\left[\left(m_{1}-n_{1}\right)^{2}+\left(m_{2}-n_{2}\right)^{2}+\left(m_{3}-n_{3}\right)^{2}\right]}
$$

9.Adım: Yakınlık katsayılarının alternatifler için bulunması

Tüm alternatifler için yakınlık katsayıları 22 numaralı formüle göre hesaplanır.

$$
C C_{i}=\frac{d_{i}^{-}}{d_{i}{ }^{*}+d_{i}{ }^{-}} \quad, i=1,2, \ldots, m
$$

10.Adım: Alternatiflerin Sıralanması

Her bir alternatif için hesaplanan yakınlık katsayılarına göre en büyük sayıdan en küçüğe doğru sıralama yapılır. En büyük yakınlık katsayısına sahip alternatif, alternatif çözüm olarak seçilir. Yakınlık katsayısı yüksek ise alternatif bulanık pozitif ideal çözüme daha yakın, bulanık negatif ideal çözüme de daha uzaktır.

\section{UYGULAMA}

Bu çalışma Otomotiv Yedek Parça sektöründe faaliyet gösteren bir eşdeğer yedek parça üreticisi firmada ortaya çıkan yeni bir proje için yapılmıştır. Uygulama aşaması 4 aşamalı olarak gerçekleştirilmiştir.

\section{A. Amaç, Kriter ve Alternatiflerin Belirlenmesi}


Bu çalışmanın amacı yeni bir pazara giren firmanın o pazarda satışı gerçekleşen bir otomobil markasının ön süspansiyonunda kullanılan salıncak parçasının eşdeğer parça olarak üretme-satın alma kararı için yapıılmıştır.

$\mathrm{Bu}$ üretme-satın alma probleminde karar vericiler müdür ve üst seviye yöneticiler olmak üzere makale yazarı da dahil 10 kişilik bir yönetici grubu olarak belirlenmiştir. Makale yazarı tarafından yapılan literatür araştırmaları sonucunda literatürde üretme-satın alma kararları ile ilgili çalışmalar incelenerek bu çalışmalar içindeki kriterler arasından uzmanlar tarafından en uygun kriterler seçilmiştir. Aynı zamanda karar sürecinde yer alan yöneticilerin belirledikleri kriterler de bu değerlendirmeye dahil edilmiştir. Sonrasında karar vericiler tarafından bu üretme-satın alma problemi için önemli olduğu düşünülen kriterler 4 ana kriter ve 20 alt kriter olarak belirlenmiştir. Kriterler dışında üretme-satın alma alternatifleri de yine aynı yöneticiler tarafından beş farklı alternatif olarak belirlenmiştir. Ana kriterler, alt kriterler ve alternatifler ile alt kriterler ve alternatiflerin kodlamaları Tablo 4'te verilmiştir.

Tablo 4: Ana Kriter, Alt Kriter ve Alternatifler

\begin{tabular}{|c|c|c|c|}
\hline Ana Kriter & $\begin{array}{c}\text { Alt Kriter } \\
\text { Kodu }\end{array}$ & Alt Kriter & Alternatif ve Kodu \\
\hline \multirow{5}{*}{$\begin{array}{l}\text { Finansal } \\
\text { Değerlendirme }\end{array}$} & $\mathrm{K} 1$ & Birim parça maliyeti & \multirow{20}{*}{$\begin{array}{l}\text { A1-Bitmiş olarak üretim } \\
\text { A2-Bitmiş olarak satın alma } \\
\text { Rotilsiz burçlu satın alma/rotil üretim } \\
\text { Rotilli burçsuz satın alma/burç üretim } \\
\text {-Rotilsiz burçsuz üretim/rotil\&burç } \\
\text { satın alma }\end{array}$} \\
\hline & $\mathrm{K} 2$ & Yatırım maliyeti & \\
\hline & K3 & Genel giderler & \\
\hline & K4 & Ödeme koşulları & \\
\hline & K5 & Nakliye maliyeti & \\
\hline \multirow{5}{*}{$\begin{array}{l}\text { Operasyonel } \\
\text { Değerlendirme }\end{array}$} & K6 & Değişiklik yönetimi & \\
\hline & K7 & Pazara giriş süresi & \\
\hline & K8 & Talep dalgalanmalarından etkilenme & \\
\hline & K9 & Tedariğin aksaması/kesilmesi riski & \\
\hline & K10 & $\begin{array}{l}\text { Üretime geçiş sonrası taleplere hızlı yanıt } \\
\text { verme }\end{array}$ & \\
\hline \multirow{5}{*}{$\begin{array}{c}\text { Stratejik } \\
\text { Değerlendirme }\end{array}$} & K11 & Ürüne sahip olma & \\
\hline & K12 & Şirketin rakiplere göre tanınma hedefleri & \\
\hline & K13 & Verimlilik & \\
\hline & K14 & İşgücü planlaması & \\
\hline & K15 & $\begin{array}{l}\text { Aynı sürede daha basit ve daha fazla ürün } \\
\text { devreye alma }\end{array}$ & \\
\hline \multirow{5}{*}{$\begin{array}{l}\text { Kalite } \\
\text { Değerlendirmesi }\end{array}$} & K16 & Üretim esnasında ortaya çıkabilecek hatalar & \\
\hline & K17 & Proses ve makine yeterlilik kontrolleri & \\
\hline & K18 & Genel ürün kalite kontrol süreçleri & \\
\hline & K19 & Satış sonrası kalite/garanti sorumluluğu & \\
\hline & K20 & Alanında uzmanlaşmış üreticilerin kalitesi & \\
\hline
\end{tabular}

\section{B. Ana Kriterler Arasındaki İlişkinin ve Kriter Ă̆ırlıklarının Tespit Edilmesi}

Bu aşamada ana kriterler arasındaki ilişki ve kriter ağırlıkları 4. bölüm 2. kısımda aktarıldığı üzere Bulanık DEMATEL yöntemi ile bulunur.

1.Adım: Kriterlerin belirlenmesi ve bulanık değerlendirme skalasının oluşturulması

Bu adımda 10 karar vericiden alınan veriler bulanık skalaya göre bulanık sayılara dönüştürülür.

2.Adım: Bulanık direkt ilişki matrisinin oluşturulması

10 karar vericinin bulanık sayılara dönüştürdüğü matrislerin ortalaması alınarak bulanık direkt ilişki matrisi Tablo 5'te olduğu gibi tespit edilir. 
Tablo 5: Bulanık direkt ilişki matrisi

\begin{tabular}{|c|c|c|c|c|c|c|c|c|c|c|c|c|}
\hline \multirow{2}{*}{$\begin{array}{c}\text { Bulanık Direkt İlişki } \\
\text { Matrisi }\end{array}$} & \multicolumn{3}{|c|}{$\begin{array}{c}\text { Finansal } \\
\text { Değerlendirme }\end{array}$} & \multicolumn{3}{|c|}{$\begin{array}{c}\text { Operasyonel } \\
\text { Değerlendirme }\end{array}$} & \multicolumn{3}{|c|}{$\begin{array}{c}\text { Stratejik } \\
\text { Değerlendirme }\end{array}$} & \multicolumn{3}{|c|}{$\begin{array}{c}\text { Kalite } \\
\text { Değerlendirmesi }\end{array}$} \\
\hline & 1 & $\mathrm{~m}$ & $\mathrm{u}$ & 1 & $\mathrm{~m}$ & $\mathrm{u}$ & 1 & $\mathrm{~m}$ & $\mathrm{u}$ & 1 & $\mathrm{~m}$ & $\mathrm{u}$ \\
\hline Finansal Değerlendirme & 0,00 & 0,00 & 0,25 & 0,15 & 0,28 & 0,53 & 0,50 & 0,75 & 0,93 & 0,03 & 0,20 & 0,45 \\
\hline Operasyonel Değerlendirme & 0,10 & 0,33 & 0,58 & 0,00 & 0,00 & 0,25 & 0,40 & 0,65 & 0,85 & 0,60 & 0,85 & 0,95 \\
\hline Stratejik Değerlendirme & 0,50 & 0,75 & 0,95 & 0,23 & 0,43 & 0,63 & 0,00 & 0,00 & 0,25 & 0,23 & 0,48 & 0,73 \\
\hline Kalite Değerlendirmesi & 0,03 & 0,23 & 0,48 & 0,48 & 0,73 & 0,93 & 0,38 & 0,63 & 0,85 & 0,00 & 0,00 & 0,25 \\
\hline Toplam u & \multicolumn{3}{|c|}{2,25} & \multicolumn{3}{|c|}{2,325} & \multicolumn{3}{|c|}{2,875} & \multicolumn{3}{|c|}{2,375} \\
\hline
\end{tabular}

3.Adım: Normalize bulanık direkt ilişki matrisinin oluşturulması

2 ve 3 numaralı formüllere göre bulanık direkt ilişki matrisi normalize edilir. Tablo 6'da gösterilmiştir.

Tablo 6: Normalize bulanık direkt ilişki matrisi

\begin{tabular}{|c|c|c|c|c|c|c|c|c|c|c|c|c|}
\hline \multirow{2}{*}{$\begin{array}{c}\text { Normalize Bulanık Direkt } \\
\text { İlişki Matrisi }\end{array}$} & \multicolumn{3}{|c|}{$\begin{array}{c}\text { Finansal } \\
\text { Değerlendirme }\end{array}$} & \multicolumn{3}{|c|}{$\begin{array}{c}\text { Operasyonel } \\
\text { Değerlendirme }\end{array}$} & \multicolumn{3}{|c|}{$\begin{array}{c}\text { Stratejik } \\
\text { Değerlendirme }\end{array}$} & \multicolumn{3}{|c|}{$\begin{array}{c}\text { Kalite } \\
\text { Değerlendirmesi }\end{array}$} \\
\hline & 1 & $\mathrm{~m}$ & $\mathrm{u}$ & 1 & $\mathrm{~m}$ & $\mathrm{u}$ & 1 & $\mathrm{~m}$ & $\mathrm{u}$ & 1 & $\mathrm{~m}$ & $\mathrm{u}$ \\
\hline Finansal Değerlendirme & 0,00 & 0,00 & 0,09 & 0,05 & 0,10 & 0,18 & 0,17 & 0,26 & 0,32 & 0,01 & 0,07 & 0,16 \\
\hline Operasyonel Değerlendirme & 0,03 & 0,11 & 0,20 & 0,00 & 0,00 & 0,09 & 0,14 & 0,23 & 0,30 & 0,21 & 0,30 & 0,33 \\
\hline Stratejik Değerlendirme & 0,17 & 0,26 & 0,33 & 0,08 & 0,15 & 0,22 & 0,00 & 0,00 & 0,09 & 0,08 & 0,17 & 0,25 \\
\hline Kalite Değerlendirmesi & 0,01 & 0,08 & 0,17 & 0,17 & 0,25 & 0,32 & 0,13 & 0,22 & 0,30 & 0,00 & 0,00 & 0,09 \\
\hline
\end{tabular}

4.Adım: Toplam bulanık direkt ilişki matrisinin oluşturulması oluşturulur.

5 numaralı formül uygulanarak 6 numaralı toplam bulanık direkt ilişki matrisi Tablo 7 de olduğu gibi

Tablo 7: Toplam bulanık direkt ilişki matrisi

\begin{tabular}{|c|c|c|c|c|c|c|c|c|c|c|c|c|}
\hline \multirow{2}{*}{$\begin{array}{c}\text { Toplam Bulanık Direkt } \\
\text { İlişki Matrisi }\end{array}$} & \multicolumn{3}{|c|}{$\begin{array}{c}\text { Finansal } \\
\text { Değerlendirme }\end{array}$} & \multicolumn{3}{|c|}{$\begin{array}{c}\text { Operasyonel } \\
\text { Değerlendirme }\end{array}$} & \multicolumn{3}{|c|}{$\begin{array}{c}\text { Stratejik } \\
\text { Değerlendirme }\end{array}$} & \multicolumn{3}{|c|}{$\begin{array}{c}\text { Kalite } \\
\text { Değerlendirmesi }\end{array}$} \\
\hline & 1 & $\mathrm{~m}$ & $\mathrm{u}$ & 1 & $\mathrm{~m}$ & $\mathrm{u}$ & 1 & $\mathrm{~m}$ & $\mathrm{u}$ & 1 & $\mathrm{~m}$ & $\mathrm{u}$ \\
\hline Finansal Değerlendirme & 0,04 & 0,14 & 1,17 & 0,07 & 0,22 & 1,26 & 0,19 & 0,39 & 1,58 & 0,04 & 0,21 & 1,26 \\
\hline Operasyonel Değerlendirme & 0,07 & 0,29 & 1,48 & 0,06 & 0,21 & 1,40 & 0,19 & 0,45 & 1,82 & 0,24 & 0,45 & 1,63 \\
\hline Stratejik Değerlendirme & 0,19 & 0,38 & 1,53 & 0,11 & 0,30 & 1,45 & 0,06 & 0,24 & 1,59 & 0,11 & 0,32 & 1,50 \\
\hline Kalite Değerlendirmesi & 0,05 & 0,25 & 1,41 & 0,19 & 0,39 & 1,54 & 0,17 & 0,41 & 1,77 & 0,05 & 0,20 & 1,38 \\
\hline
\end{tabular}

5.Adım: Neden sonuç ilişkilerinin (Gönderici alıcı gruplarının) belirlenmesi

7 ve 8 numaralı formüllere istinaden Tablo 8'deki değerler bulunur ve Şekil 2'deki neden sonuç diyagramı oluşur.

Tablo 8: $\widetilde{D}_{i}^{\text {def }}+\widetilde{R}_{i}{ }^{\text {def }}$ ve $\widetilde{D}_{i}{ }^{\text {def }}-\widetilde{R}_{i}^{\text {def }}$ değerleri

\begin{tabular}{lcc}
\hline Ana Kriter & $\widetilde{\boldsymbol{D}}_{\boldsymbol{i}}^{\text {def }}+\widetilde{\boldsymbol{R}}_{\boldsymbol{i}}^{\text {def }}$ & $\widetilde{\boldsymbol{D}}_{\boldsymbol{i}}^{\text {def }}-\widetilde{\boldsymbol{R}}_{\boldsymbol{i}}^{\text {def }}$ \\
\hline Finansal Değerlendirme & 3,90 & 0,13 \\
\hline Operasyonel Değerlendirme & 4,49 & $-0,34$ \\
\hline Stratejik Değerlendirme & 4,84 & 0,34 \\
\hline Kalite Değerlendirmesi & 4,40 & $-0,12$ \\
\hline
\end{tabular}




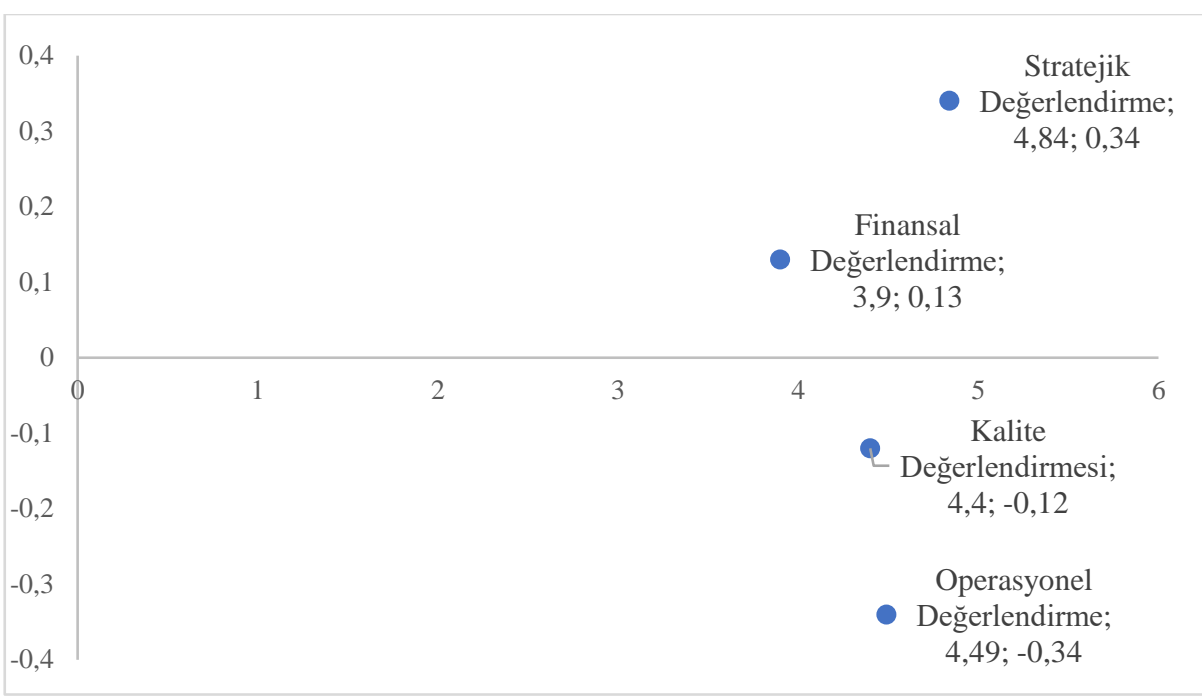

Şekil 2: Neden sonuç ilişki diyagramı

Bu diyagrama göre Kalite Değerlendirmesi ve Operasyonel Değerlendirme alıcı ya da etkilenen, Stratejik Değerlendirme ve Finansal Değerlendirme ise gönderici ya da etkileyen gruptadır. Stratejik Değerlendirme kriteri en çok etkileyen kriter olarak ortaya çıkmıştır.

6.Adım: Ana kriter ağırlıklarının belirlenmesi

9 numaralı formüle göre kriter ağırlıkları belirlenir, Tablo 9'da gösterilmiştir.

Tablo 9: Ana kriter ağırlıkları

\begin{tabular}{ccc}
\hline Ana Kriter & w & W \\
\hline Finansal Değerlendirme & 3,90 & 0,22 \\
\hline Operasyonel Değerlendirme & 4,50 & 0,25 \\
\hline Stratejik Değerlendirme & 4,86 & 0,27 \\
\hline Kalite Değerlendirmesi & 4,41 & 0,25 \\
\hline
\end{tabular}

C. Alt Kriterler Arasındaki İlişkinin ve Kriter Ă̆ırlıklarının Tespit Edilmesi

5.2.deki uygulama gibi alt kriterlerin ağırlıklarının tespiti için de aynı adımlar ilerletilir ve Tablo 10'daki gibi ağırlıklar ortaya çıkar. 
Tablo 10: Alt kriter ağırlıkları

\begin{tabular}{lll}
\hline Alt Kriter & w & W \\
\hline Birim parça maliyeti & 2,40 & 0,055 \\
Yatırım maliyeti & 1,97 & 0,045 \\
Genel giderler & 1,82 & 0,041 \\
Ödeme koşulları & 1,81 & 0,041 \\
Nakliye maliyeti & 1,71 & 0,039 \\
Değişiklik yönetimi & 2,06 & 0,047 \\
Pazara giriş süresi & 2,01 & 0,046 \\
Talep dalgalanmalarından etkilenme & 1,76 & 0,040 \\
Tedariğin aksaması/kesilmesi riski & 2,38 & 0,054 \\
Üretime geçiş sonrası taleplere hızlı yanıt verme & 2,49 & 0,057 \\
Ürüne sahip olma & 3,24 & 0,074 \\
Şirketin rakiplere göre tanınma hedefleri & 2,32 & 0,053 \\
Verimlilik & 2,76 & 0,063 \\
İşgücü planlaması & 2,74 & 0,062 \\
Aynı sürede daha basit ve daha fazla ürün devreye alma & 2,06 & 0,047 \\
Üretim esnasında ortaya çıkabilecek hatalar & 2,22 & 0,051 \\
Proses ve makine yeterlilik kontrolleri & 1,65 & 0,038 \\
Genel ürün kalite kontrol süreçleri & 2,73 & 0,062 \\
Satış sonrası kalite/garanti sorumluluğu & 2,10 & 0,048 \\
Alanında uzmanlaşmış üreticilerin kalitesi & 1,67 & 0,038 \\
\hline
\end{tabular}

\section{Alternatiflerin Değerlendirilmesi ve En İyi Alternatifin Seçimi}

Bu aşamada 4.3. bölümde anlatılan yöntem adımlarının uygulaması yapılır.

1., 2. ve 3. adımlardaki işlemler 10 karar vericiden alınan verilerle yapılır ve 4. adıma geçilir.

4.Adım: Bulanık karar matrisinin oluşturulması

10 numaralı formülasyona göre bulanık karar matrisi oluşturulur. Tablo 11'de gösterilmiştir.

Tablo 11: Bulanık karar matrisi

\begin{tabular}{|c|c|c|c|c|c|c|c|c|c|c|c|c|c|c|c|}
\hline & \multicolumn{3}{|c|}{ A1 } & \multicolumn{3}{|c|}{ A2 } & \multicolumn{3}{|c|}{ A3 } & \multicolumn{3}{|c|}{ A4 } & \multicolumn{3}{|c|}{ A5 } \\
\hline & 1 & $\mathrm{~m}$ & $\mathrm{u}$ & 1 & $\mathrm{~m}$ & $\mathrm{u}$ & 1 & $\mathrm{~m}$ & $\mathrm{u}$ & 1 & $\mathrm{~m}$ & $\mathrm{u}$ & 1 & $\mathrm{~m}$ & $\mathrm{u}$ \\
\hline K1 & 0,50 & 0,75 & 0,90 & 0,53 & 0,78 & 0,93 & 0,35 & 0,60 & 0,85 & 0,43 & 0,68 & 0,93 & 0,20 & 0,45 & 0,70 \\
\hline $\mathrm{K} 2$ & 0,55 & 0,80 & 0,95 & 0,00 & 0,10 & 0,35 & 0,13 & 0,35 & 0,60 & 0,05 & 0,28 & 0,53 & 0,23 & 0,48 & 0,73 \\
\hline K3 & 0,43 & 0,68 & 0,88 & 0,00 & 0,08 & 0,33 & 0,00 & 0,25 & 0,50 & 0,05 & 0,18 & 0,43 & 0,20 & 0,45 & 0,70 \\
\hline K4 & 0,28 & 0,53 & 0,78 & 0,55 & 0,80 & 0,93 & 0,25 & 0,50 & 0,75 & 0,13 & 0,38 & 0,63 & 0,25 & 0,50 & 0,75 \\
\hline K5 & 0,20 & 0,45 & 0,70 & 0,60 & 0,85 & 0,98 & 0,43 & 0,68 & 0,93 & 0,40 & 0,65 & 0,90 & 0,23 & 0,48 & 0,73 \\
\hline K6 & 0,30 & 0,55 & 0,80 & 0,63 & 0,88 & 0,95 & 0,38 & 0,63 & 0,88 & 0,23 & 0,48 & 0,73 & 0,25 & 0,50 & 0,75 \\
\hline K7 & 0,53 & 0,78 & 0,93 & 0,58 & 0,83 & 0,98 & 0,40 & 0,65 & 0,90 & 0,40 & 0,65 & 0,90 & 0,25 & 0,50 & 0,75 \\
\hline K8 & 0,53 & 0,78 & 0,95 & 0,25 & 0,50 & 0,75 & 0,08 & 0,28 & 0,53 & 0,03 & 0,13 & 0,38 & 0,08 & 0,25 & 0,50 \\
\hline K9 & 0,08 & 0,33 & 0,58 & 0,53 & 0,78 & 0,93 & 0,45 & 0,70 & 0,95 & 0,35 & 0,60 & 0,85 & 0,20 & 0,50 & 0,75 \\
\hline K10 & 0,60 & 0,85 & 0,98 & 0,28 & 0,53 & 0,78 & 0,25 & 0,50 & & 0,18 & 0,43 & 0,68 & 0,23 & 0,48 & 0,73 \\
\hline K11 & 0,48 & 0,73 & 0,90 & 0,00 & 0,03 & 0,28 & 0,05 & 0,25 & 0,50 & 0,05 & 0,20 & 0,45 & 0,23 & 0,48 & 0,73 \\
\hline K12 & 0,20 & 0,45 & 0,70 & 0,00 & 0,05 & 0,30 & 0,28 & 0,53 & 0,78 & 0,35 & 0,60 & 0,85 & 0,38 & 0,63 & 0,88 \\
\hline K13 & 0,40 & 0,65 & 0,90 & 0,03 & 0,20 & 0,45 & 0,05 & 0,25 & 0,50 & 0,08 & 0,33 & 0,58 & 0,10 & 0,25 & 0,50 \\
\hline K14 & 0,43 & 0,68 & 0,85 & 0,00 & 0,00 & 0,25 & 0,03 & 0,28 & 0,53 & 0,08 & 0,30 & 0,55 & 0,18 & 0,43 & 0,68 \\
\hline K15 & 0,45 & 0,70 & 0,95 & 0,00 & 0,05 & 0,30 & 0,00 & 0,08 & 0,33 & 0,00 & 0,00 & 0,25 & 0,00 & 0,08 & 0,33 \\
\hline K16 & 0,18 & 0,43 & 0,68 & 0,40 & 0,65 & 0,90 & 0,45 & 0,70 & 0,93 & 0,38 & 0,63 & 0,88 & 0,30 & 0,55 & 0,80 \\
\hline K17 & 0,68 & 0,93 & 1,00 & 0,03 & 0,10 & 0,35 & 0,03 & 0,15 & 0,40 & 0,10 & 0,33 & 0,58 & 0,03 & 0,23 & 0,48 \\
\hline K18 & 0,50 & 0,75 & 0,88 & 0,45 & 0,70 & 0,95 & 0,30 & 0,55 & 0,80 & 0,18 & 0,43 & 0,68 & 0,25 & 0,50 & 0,75 \\
\hline K19 & 0,58 & 0,83 & 0,95 & 0,18 & 0,43 & 0,68 & 0,28 & 0,53 & 0,78 & 0,18 & 0,43 & 0,68 & 0,23 & 0,48 & 0,73 \\
\hline K20 & 0,00 & 0,05 & 0,30 & 0,50 & 0,75 & 0,90 & 0,45 & 0,70 & 0,93 & 0,40 & 0,65 & 0,90 & 0,45 & 0,70 & 0,93 \\
\hline
\end{tabular}

5.Adım: Normalize edilmiş bulanık karar matrisinin oluşturulması 
Bulunan bulanık karar matrisi 13 ve 14 formüllerine göre normalize edilir ve 15 numaralı formülde yer alan normalize edilmiş bulanık karar matrisi bulunur.

6.Adım: Ağırlıklı normalize edilmiş bulanık karar matrisinin oluşturulması

5.3. bölümde bulunan alt kriter ağırlıkları normalize edilmiş bulanık karar matrisi ile çarpılarak yani 16 numaralı formül uygulanarak ağırlıklı normalize edilmiş bulanık karar matrisi oluşturulur.

7.Adım: Bulanık pozitif ve negatif ideal çözümlerin belirlenmesi

$$
\begin{aligned}
& A^{*}=[(1,1,1),(1,1,1),(1,1,1),(1,1,1),(1,1,1)] \\
& A^{-}=[(0,0,0),(0,0,0),(0,0,0),(0,0,0),(0,0,0)]
\end{aligned}
$$

\section{Adım: Yakınlık katsayılarının hesaplanması}

5 alternatif çözümün 20 kritere göre pozitif ve negatif uzaklıkları öncelikle 21 numaralı formüldeki Vertex yöntemine göre hesaplanır. Sonrasında 19 ve 20 numaralı formüllerde olduğu gibi tablolar oluşturularak 9.adıma geçilir.

9.Adım: Yakınlık katsayılarının alternatifler için bulunması

5 alternatifin de tüm kriterler için pozitif ve negatif ideal çözüme uzaklıklarının hesaplanmasının ardından alternatifler için $d_{i}{ }^{*}$ ve $d_{i}{ }^{-}$değerleri elde edilir ve 22 numaralı formülasyona göre her alternatif için CCi yakınlık katsayıları bulunur. Tablo 12 'de verilmiştir.

Tablo 12: Her alternatif için yakınlık katsayılarının bulunması

\begin{tabular}{clllll}
\hline & $\mathbf{A 1}$ & $\mathbf{A 2}$ & $\mathbf{A 3}$ & $\mathbf{A 4}$ & $\mathbf{A 5}$ \\
\hline $\boldsymbol{d}_{\boldsymbol{i}}{ }^{-}$ & 19,38 & 19,54 & 19,52 & 19,54 & 19,51 \\
\hline $\boldsymbol{d}_{\boldsymbol{i}}{ }^{-}$ & 0,65 & 0,50 & 0,53 & 0,51 & 0,53 \\
\hline $\boldsymbol{d}_{\boldsymbol{i}}{ }^{+} \boldsymbol{d}_{\boldsymbol{i}}{ }^{-}$ & 20,03 & 20,04 & 20,05 & 20,05 & 20,05 \\
\hline $\mathrm{CCi}$ & 0,0326 & 0,0250 & 0,0264 & 0,0253 & 0,0266 \\
\hline
\end{tabular}

\section{Adım: Alternatiflerin sıralanması}

CCi yani alternatiflerin yakınlık katsayılarını büyükten küçüğe doğru sıralandığında A1>A5>A3>A4>A2 olarak çıkmıştır. Yani sırasıyla 1 numaralı alternatif çözüm "Bitmiş olarak üretim" yapmak şeklinde çıkmış sonrasında alternatifler "Rotilsiz burçsuz satınalma/rotil\&burç üretim", "Rotilsiz burçlu satınalma/rotil üretim", "Rotilli burçsuz satınalma/burç üretim", "Bitmiş olarak satınalma" şeklinde sıralanmıştır.

\section{SONUÇLAR}

Bu çalışmada üretme-satın alma kararlarının çözümünde kullanılan bu bütünleşik yöntemle birlikte otomotiv yedek parça sektöründe yeni pazara giren firmanın o pazarda satı̧ıı gerçekleşen bir otomobil markasının ön süspansiyonunda kullanılan salıncak parçasının eşdeğer yedek parça olarak üret kararı ortaya çıkmışıır. Bu demek oluyor ki pazara hızlı giriş yapmaktansa stratejik karar vermek, ürüne maliyet, kalite, hız ve esneklik olarak tümüyle hakim olmak çok daha büyük bir öneme sahip olmaktadır. Hatta alternatiflerin sıralanmasında ortaya çıkan sonuç satın alma yapmanın bu proje için en son tercih edilmesi gerektiğini ortaya koymuştur. Aynı zamanda bu sektörde yer alan firmalar genel olarak rotilleriyle ön plana çıktığı için bu karar sürecindeki alternatiflerin sıralamasında da ilk 3 aşamada rotilin üretim olması kararı ortaya çıkarak bu stratejik kararı da desteklemiş̧ir.

$\mathrm{Bu}$ çalışmanın aşağıdaki alanlarda fayda sağlayacă̆ öngörülmektedir;

- Üretme-satın alma karar problemlerinin çözümünde kriterler arasındaki ilişkilerin belirlenmesinde Bulanık DEMATEL yöntemi ilk defa, alternatif çözüm önerilerinin sıralanması ve içlerinden en iyisinin tespiti 
noktasında da Bulanık TOPSIS yöntemi kullanılmıştır. Kısacası karar problemi entegre ya da bütünleşik olarak tabir edilen bir yöntemle çözülmüştür. Üretme-satın alma karar probleminin çözümünde Bulanık DEMATEL ve Bulanık TOPSIS yöntemlerinin kullanıldığ 1 ilk uygulama olması nedeniyle çalışma literatürde bir ilk olmuştur.

- Hazırlanmış olan bu bütünleşik çalışma metodolojisi üretme-satın alma kararının sıkça verildiği otomotiv yedek parça sektöründe uygulanarak bu karar probleminin çözümüne bilimsel bir yaklaşım getirmiştir.

- Üretme-satın alma karar problemi disiplinler arası bir süreçle yönetilmesi gerekirken çok az kişinin ortak kararı ile yürütülerek sonraki aşamalarda görüşü alınmayan alanlarla ilgili sorunlarla karşılaşıldığı göze alınarak süreçte yer alması gereken tüm disiplinler karar verme sürecine ortak edilmişlerdir.

Üretme-satın alma karar problemine ilk defa uygulanan bu bütünleşik yöntem gelecek çalışmalarda farklı Bulanık ÇKKV yöntemlerinin kullanılmasıyla sonuçların karşılaştırılabileceği farklı modeller de ele alınabilir.

\section{KAYNAKLAR}

[1] Arslan, A.E., \& Acar, M.Ş., \& Arslan, O. (2019). O-Tipi Orc-Bınary Jeotermal Güç Santralı Optimizasyonu: Eatwos Analizi, Bilecik Şeyh Edebali Üniversitesi Fen Bilimleri Dergisi, Prof. Dr. Fuat SEZGIN Bilim Y1lı Özel Sayıs1, 6, 222-236.

[2] Bergen, S.A. (1977). The make or buy decision. $R \& D$ Management, 8, 1, 39-42.

[3] Bigelow, L.S., \& Argyres, N. (2008). Cengel, Y. A., \& Boles, M. A. (2002). Transaction costs, industry experience and make-or-buy decisions in the population of early U.S. auto firms. Journal of Economic Behavior\&Organization, Vol.66, 791-807.

[4] Büyüközkan, G., \& Çiftçi, G. (2012). A Novel Hybrid MCDM Approach Based On Fuzzy DEMATEL, Fuzzy ANP And Fuzzy TOPSIS To Evaluate Green Suppliers. Expert Systems with Applications, 39, 30003011.

[5] Canez, L.E., \& Platts, K.W., \& Probert, D.R. (2000). Developing a framework for make-or-buy decisions. International Journal of Operations \& Production Management, Vol. 20, No. 11, 1313-1330.

[6] Coase, R.H. (1937). The Nature of the Firm. Economica, Vol.4, 386-405.

[7] Chen, C.T. (2000). Extensions of the TOPSIS for group decision making under fuzzy environment. Fuzzy Set and Systems, 114, 1-9.

[8] Cheshmberah, M., \& Makui, A., \& Seyedhoseini, S.M. (2010). Manufacturing outsourcing decision making based on screening core activities and Fuzzy multi-criteria approach. Journal of Applied Sciences, X, 19, 2276-2282.

[9] Dalalah, D.\& Hayajneh, M., \& Batieha, F. (2011). A Fuzzy Multi-Criteria Decision Making Model for Supplier Selection, Expert Systems with Applications, 38(7), 8384-8391.

[10] Ford, W.H., \& Porter H.F. (1915). Deciding whether to buy or to make, Library Factory Management Supply, 3, 45-52.

[11] Ford, D., \& Farmer, D. (1986). Make or buy - a key strategic issue, Long Range Planning, XIX, 5, 54-62.

[12] Hwang, H.S., \& Ko, W-H., \& Goan, M-J. (2007). Web-based multi-attribute analysis model for make-orbuy decisions, Mathematical and Computer Modelling, XLVI, 7, 1081-1090.

[13] Kahraman, C., \& Engin, O., \& Kabak, Ö., \& Kaya, İ. (2008). Information systems outsourcing decisions using a group decision-making approach, Engineering Applications of Artificial Intelligence 22, 832-841.

[14] Karakuzu, C., \& Makhaila, A.A. (2017). Veriye Dayalı Bulanık Mantık Tabanlı Dinamik Sistem Modelleme, Bilecik Şeyh Edebali Üniversitesi Fen Bilimleri Dergisi, 4, 9-29. 
[15] Li, R.J. (1999). Fuzzy Method in Group Decision Making. Computers and Mathematics with Applications, 38(1), 91-101.

[16] Lin, C.J., \& Wu, W.W. (2008). A Causal Analytical Method For Group Decision-Making Under Fuzzy Environment, Expert Systems with Applications, Volume 34, Issue 1, 205-213.

[17] Minh, N.D. (2011). Empirical make-or-buy decision making model in the Japanese Automobile Industry, Proceedings of the 2011 Winter Simulation Conference, 647-658.

[18] Moschuris, S. (2007). Triggering Mechanisms in Make-or-Buy Decisions: An Empirical Analysis, Journal of Supply Chain Management, XLIII, 1, 40-49.

[19] Öncü, A.A., \& Öner, M.A., \& Başoğlu, N. (2006). Make or Buy Analysis for Local Manufacture or Import Decisions in Defense System Procurements Using AHP: The Case of Turkey, Yapı Kredi Economic Review, XVII, 1, 39-59.

[20] Özbıyık, G. (2010). Çok kriterli karar verme yöntemleri ile Isısan A.Ş.’de üret veya satın al kararlarının uygulanması, Yüksek Lisans Tezi, Kayseri Erciyes Üniversitesi, Fen Bilimleri Fakültesi, Kayseri.

[21] Padillo, J.M., \& Diaby, M. (1999). A multiple-criteria decision methodology for the make-or-buy problem, International Journal of Production Research, XXXVII, 14, 3203-3229.

[22] Platts, K.W., \& Probert, D.R., \& Canez, L. (2002). Make vs. buy decisions: A process incorporating multiattribute decision-making, International Journal of Production Economics, LXXVII, 3, 247-257.

[23] Probert, D.R. (1996). The practical development of a make or buy strategy: the issue of process positioning, Integrated Manufacturing Systems, 7 (2), 44-51.

[24] Şentan, M.A. 2013. Üret veya satın al karar sürecine yönelik çözüm önerisi: Savunma sanayi uygulaması, Yüksek Lisans Tezi, Kara Harp Okulu, Savunma Bilimleri Enstitüsü, Ankara.

[25] Van de Water, H., \& Van Peet, H.P. (2007). A decision support model based on the Analytic Hierarchy Process for the Make or Buy decision in manufacturing, Journal of Purchasing and Supply Management,12, 258-271.

[26] Wang, J., \& Yang, D. (2007). Using a hybrid multi-criteria decision aid method for information systems outsourcing, Computers \& Operations Research, XXXIV, 12, 3691-3700.

[27] Yoon, K.P., \& Naadimuthu, G. (1994). A make-or-buy decision analysis involving imprecise data, International Journal of Operations \& Production Management XIV, 2, 62-69.

[28] Zadeh, L.A. (1965). Fuzzy sets, Information Control, 8, 338-353.

[29] Williamson, O.E. (1975). Markets and Hierarchies, New York, 26-30. 